\title{
Uwagi do polskiego systemu pozasądowej kompensacji szkód medycznych na tle nowozelandzkiego Injury Prevention, Rehabilitation, and Compensation Act
}

\author{
Remarks on the Polish out-of-court compensation system of medical injuries \\ in the context of the Injury Prevention, Rehabilitation, and Compensation Act \\ Комментарии к польской системе внесудебной компенсации медицинских \\ травм в сравнении с новозеландским Injury Prevention, Rehabilitation, \\ and Compensation Act
}

MICHAŁ BIAŁKOWSKI

Dr, Uniwersytet Szczeciński

e-mail: michal.bialkowski@usz.edu.pl, https://orcid.org/0000-0002-3366-6883

\begin{abstract}
Streszczenie: Dochodzenie przez pacjenta roszczeń związanych ze szkodą doznaną przez niego w toku leczenia napotyka w praktyce liczne trudności, począwszy od tych związanych z udowodnieniem przesłanek odpowiedzialności, na kosztach i długotrwałości procesu skończywszy. W konsekwencji w wielu systemach prawnych na świecie podjęto próby projektowania pozasądowych systemów kompensacyjnych opartych na ubezpieczeniu na rzecz pacjenta albo na funduszu gwarancyjnym mającym zrekompensować doznany przez pacjenta uszczerbek. Celem artykułu jest porównanie najdłużej funkcjonującego systemu typu no-fault, który w Nowej Zelandii w obecnej formie zapewnia naprawienie szkody pacjentom od 1 stycznia 2002 r., oraz działającego od 1 stycznia 2012 r. systemu polskiego. Analiza skupia się na trzech płaszczyznach, tj. konieczności wykazania naruszenia zasad wiedzy medycznej jako przesłanki odpowiedzialności, zakresu definicji zdarzenia medycznego i treatment injury oraz ustalenia kręgu osób posiadających uprawnienie w obu analizowanych systemach do dochodzenia świadczenia odszkodowawczego. Na tym tle sformułowane zostały szczegółowe postulaty de lege ferenda, co do zmiany przepisów ustawy o prawach pacjenta i Rzeczniku Praw Pacjenta dotyczące w szczególności odejścia od konieczności wykazania obiektywnego naruszenia zasad wiedzy medycznej jako przesłanki odpowiedzialności, odejścia od różnicowania szkód powstałych w szpitalach oraz poza nimi, jak i rozszerzenia zakresu definicji zdarzenia medycznego o szkody powstałe $w$ związku z naruszeniem praw pacjenta i szeroko rozumianą profilaktyką leczenia. W artykule proponuje się również rezygnację z ustalenia kręgu podmiotów pośrednio poszkodowanych przez pryzmat posiadania formalnego statusu spadkobiercy na rzecz znanego z przepisów art. 446 § 3 i 4 Kodeksu cywilnego zabiegu polegającego na powiązaniu uprawnienia do dochodzenia świadczenia odszkodowawczego w przypadku śmierci pacjenta z rzeczywistą więzią emocjonalną łączącą zmarłego $z$ wnioskodawcą.
\end{abstract}

Słowa kluczowe: zdarzenie medyczne, nowozelandzkie treatment injury, system typu no-fault, alternatywne metody rozwiązywania sporów, naprawienie szkody, szkoda na osobie, błąd medyczny, osoba pośrednio poszkodowana

Summary: Seeking redress by the patient due to damage sustained by him in the course of treatment encounters numerous difficulties. They range from those related with proving prerequisites of civil liability to costs and duration of the process. As a consequence, many legal systems around the world have attempted to design out-of-court compensation systems based on the first-party insurance of the patient or on a fund whose purpose is to compensate the damage suffered by the patient during treatment. The aim of this article is to compare the longest functioning no-fault system, which in New Zealand in its present form provides redress 
to patients from 1 January 2002, and the Polish system that has been operating since 1 January 2012. The analysis focuses on three aspects, i.e., the need to demonstrate a violation of the principles of medical knowledge as a premise of liability, the scope of the definition of a medical event and treatment injury, and to establish the group of people authorized in both analyzed systems to claim compensation. Against this background, detailed de lege ferenda postulates have been formulated regarding the amendment of the provisions of the Act on Patient Rights and the Patient's Rights Ombudsman regarding, in particular, the departure from the need to demonstrate an objective violation of the principles of medical knowledge as a premise for liability, departing from the differentiation of damages incurred in hospitals and outside them, as well as extending the scope of the definition of a medical event to include damages caused in connection with the violation of patient's rights and broadly understood preventive treatment. The article also proposes resignation from establishing the group of entities indirectly injured through the prism of having the status of heirs in favor of the known from the provisions of art. $446 \S 3$ and 4 of the Civil Code based on linking the right to claim compensation in the event of the patient's death with the actual emotional bond between the deceased and the applicant.

Key words: medical event in Poland, treatment injury in New Zealand, no-fault system, alternative dispute resolution, compensation, personal injury, medical malpractice, indirectly injured entities

Резюме: На практике предъявление пациентом претензий, связанных с ущербом, понесенным в ходе лечения, сталкивается с многочисленными трудностями, начиная с доказательств предпосылок ответственности и заканчивая затратами и длительностью процесса. В связи с этим во многих правовых системах мира предпринимались попытки разработать внесудебные системы компенсации, основанные на страховании в пользу пациента или гарантийном фонде для возмещения вреда, причиненного пациенту. Цель статьи - сравнить дольше всего действующую систему no-fault, которая в Новой Зеландии в ее нынешнем виде предоставляет компенсации пациентам с 1 января 2002 года, и польскую систему, действующую с 1 января 2012 года. Анализ сосредоточен на трех уровнях, а именно это: необходимость доказывания нарушения принципов медицинских знаний как предпосылки ответственности, толкование термина медицинское событие и treatment injury, а также определение круга лиц, имеющих право требовать компенсации в обеих анализируемых системах. На этом фоне были сформулированы подробные постулаты de lege ferenda в отношении изменения положений Закона о правах пациента и Уполномоченного по правам пациента, касающиеся, в частности, отказа от необходимости доказывания объективного нарушения медицинских знаний как предпосылки ответственности, отказа от дифференциации ущерба, возникающего в больницах и вне их, а также расширения объема толкования термина медицинское событие за счет ущерба, возникающего в связи с нарушением прав пациента и широко понимаемой профилактики. В статье также предлагается отказаться от определения круга субъектов, косвенно пострадавших через призму обладания формальным статусом наследника, в пользу процедуры, известной из положений статьи 446 § 3 и 4 Гражданского кодекса, заключающейся в связывании права требовать компенсации в случае смерти пациента с фактической эмоциональной связью, соединяющей умершего с истцом.

Ключевые слова: медицинское событие, новозеландское treatment injury, система no-fault, альтернативное разрешение споров, компенсация ущерба, травма, врачебная ошибка, косвенно пострадавшее лицо

\section{Wstęp}

Ochrona pacjenta, który doznał uszczerbku w toku leczenia od wielu lat i w wielu państwach zdecydowanie wykracza poza prawo cywilne, stając się przedmiotem zainteresowania teorii i praktyki innych gałęzi prawa, w szczególności administracyjnego, ubezpieczeniowego czy zabezpieczenia społecznego ${ }^{1}$. Owo poszukiwanie

1 J. Jończyk, Między odpowiedzialnością lekarza a ubezpieczeniem pacjenta, Prawo i Medycyna 1990, nr 3, s. 5. 
innych rozwiązań również na gruncie gałęzi prawa, które nie są kojarzone z regulowaniem tradycyjnie pojmowanych zasad odpowiedzialności cywilnej, stanowi dowód na istnienie kryzysu nazywanego w literaturze zachodniej malpractice cri$s i s^{2}$. Podejmowane próby zmian w ustawodawstwach krajów, takich jak Nowa Zelandia, Szwecja czy Francja, które chciały wprowadzić systemy typu no-fault albo arbitrażowe, miały na celu umożliwienie dokonania szybkiego i pełnego zrekompensowania doznanych przez pacjentów szkód w toku procesu leczniczego ${ }^{3}$. W literaturze zachodniej przyczyn kryzysu w obrębie problematyki naprawienia szkody powstałej przy leczeniu poszukuje się także w długotrwałości procesów odszkodowawczych czy wysokości kosztów postępowania przed sądem ${ }^{4}$.

W konsekwencji przełom XX i XXI w. przyniósł zjawisko nazywane w nauce prawa „kolektywizacją” prawa czynów niedozwolonych, która z jednej strony polega na znaczącej ekspansji ubezpieczeń, akceptacji odpowiedzialności za niebezpieczną działalność przedsiębiorstwa oraz wprowadzenie instrumentów prawnych umożliwiających rozłożenie ciężaru naprawienia szkody na wiele podmiotów (kolektywizacja wewnętrzna), z drugiej zaś sprowadza się do wyłączenia określonych rodzajów stanów faktycznych spod ogólnych reguł odpowiedzialności deliktowej i poddanie ich specjalnym pozasądowym reżimom indemnizacyjnym ${ }^{5}$. Celem kolektywizacji jest usprawnienie i obniżenie kosztów dochodzenia roszczeń, poprzez rozważenie możliwości przesunięcia indemnizacji szkód na osobie w kierunku prawa publicznego w drodze tworzenia funduszy, czy systemów kompensacji o charakterze ściśle administracyjnym albo mieszanym (w sensie łączenia środków publicznych ze środkami pochodzącymi z ubezpieczeń prywatnych) ${ }^{6}$. Już od lat 70. XX w. w wielu krajach europejskich oraz w USA ${ }^{7}$ wprowadzone zostały rozwiązania zmierzające do stworzenia bardziej efektywnego mechanizmu rekompensaty zarówno zawinionych, jak i niezawinionych „szkód medycznych”.

2 K. Bączyk-Rozwadowska, Odpowiedzialność cywilna za szkody wyrządzone przy leczeniu, Toruń 2013, s. 209.

3 M. Nesterowicz, Prawo medyczne, Toruń 2010, s. 417-419.

4 M. Nesterowicz, Prawo..., s. 417-419; S. Mc Lean, No Fault Compensation Review Group Report and Recommendations Volume I, Scottish Government 2011, https:/www.scotland.gov.uk/Resource/0040/00401664.doc [dostęp: 5.10.2020 r.]; J. Cooper, R. Egeberg, S. Stephens, Where is the malpractice crisis taking us?, The Western Journal of Medicine 1977, nr 127 (3), s. 262.

5 E. Bagińska, Tendencje rozwojowe odpowiedzialności deliktowej w Europie w końcu XX i początkach XXI wieku, w: Czyny niedozwolone w prawie polskim i prawie porównawczy, red. M. Nestorowicz, Warszawa 2012, s. 74-75.

6 Tamże, s. 75.

7 J. Cooper, R. Egeberg, S. Stephens, Where is..., s. 262. 
Również w Polsce ustawą z dnia 28 kwietnia 2011 r. o zmianie ustawy o prawach pacjenta i Rzeczniku Praw Pacjenta oraz ustawy o ubezpieczeniach obowiązkowych, Ubezpieczeniowym Funduszu Gwarancyjnym i Polskim Biurze Ubezpieczycieli Komunikacyjnych ${ }^{8}$ zostały wprowadzone przepisy dotyczące trybu i zasad ustalania odszkodowania i zadośćuczynienia w przypadku wystąpienia zdarzeń medycznych. Nowe przepisy, które weszły w życie 1 stycznia 2012 r., są - podobnie jak miało to miejsce na świecie - odpowiedzią na rosnącą liczbę tzw. procesów medycznych i potrzebę ułatwienia pacjentom dochodzenia roszczeń za szkody powstałe w związku z szeroko pojętym procesem leczniczym.

Celem artykułu jest analiza i porównanie przesłanek dochodzenia świadczenia odszkodowawczego w pozasądowym systemie kompensacji „szkód medycznych” funkcjonujących w Nowej Zelandii oraz w Polsce. Analiza ograniczona zostanie przy tym do trzech podstawowych różnic $w$ analizowanych systemach, tj. konieczności wykazania obiektywnej sprzeczności działania albo zaniechania, z którego szkoda wynikła, z aktualną wiedzą medyczną, zakresu definicji zdarzenia medycznego i treatment injury oraz ustalenia kręgu osób posiadających uprawnienie do dochodzenia świadczenia odszkodowawczego. Wybór systemu nowozelandzkiego, jako materiału porównawczego dla tego wprowadzonego w Polsce, podyktowany jest po pierwsze tradycją (był to pierwszy system tego typu na świecie) oraz jego stabilnością (system działa - ze zmianami - od 1 kwietnia 1974 r.) i po drugie jego wysoką skutecznością. W Polsce zgodnie z raportem Najwyższej Izby Kontroli w latach 2012-2017 do zbadanych ośmiu wojewódzkich komisji do spraw orzekania o zdarzeniach medycznych (dalej: komisja/wojewódzka komisja) wpłynęło łącznie 2203 wniosków o ustalenie zdarzenia medycznego, spośród których orzeczenie o ustaleniu zdarzenia medycznego zapadło jedynie w 431 wypadkach ${ }^{9}$. Oznacza to, że jedynie w 19,6\% przypadków złożony przez pacjenta wniosek został pozytywnie dla niego rozpatrzony ${ }^{10}$. W Nowej Zelandii natomiast w latach 2011-2016 zaobserwowano stały poziom uwzględnianych wniosków o rekompensatę doznanych uszczerbków na osobie na poziomie ok. $63-65 \%{ }^{11}$. Stopniowo wprowadzany

8 Dz. U. Nr 113, poz. 660.

9 Pozasądowe dochodzenie roszczeń przez pacjentów. Raport NIK, https://www.nik.gov.pl/ kontrole/P/18/057/, s. 45-48 [dostęp: 16.11.2020 r].

10 Przytoczone dane abstrahują od informacji dotyczących faktycznie przyjętych przez pacjenta albo jego spadkobierców propozycji podmiotu leczniczego albo jego ubezpieczyciela co do zapłaty odszkodowania lub zadośćuczynienia. Te zaś wskazują, że faktyczny odsetek spraw zakończonych uzyskaniem świadczenia przez poszkodowanego ograniczony jest do ok. $10 \%$ spraw (Pozasq̨dowe dochodzenie..., s. 44-49).

11 Accident Compensation Corporation, Supporting Patient Safety: Treatment Injury Information, Wellington 2017, s. 40-41. 
i zmieniany na przestrzeni lat system doprowadził na antypodach praktycznie do zupełnego zaniku sporów sądowych dotyczących szkód powstałych na osobie ${ }^{12}$.

\section{Wybrane problemy polskiego systemu pozasądowej kompensacji szkód medycznych}

W polskim porządku prawnym definicje zdarzenia medycznego zawiera art. $67 \mathrm{a}$ ust. 1 i 2 ustawy z dnia 6 listopada 2008 r. o prawach pacjenta i Rzeczniku Praw Pacjenta ${ }^{13}$. Zgodnie z przywołanym przepisem zdarzeniem medycznym jest mające miejsce w szpitalu w rozumieniu ustawy z dnia 15 kwietnia 2011 r. o działalności leczniczej ${ }^{14}$ zakażenie pacjenta biologicznym czynnikiem chorobotwórczym, uszkodzenie ciała lub rozstrój zdrowia pacjenta albo śmierć pacjenta będące następstwem niezgodnych z aktualną wiedzą medyczną:

1) diagnozy, jeżeli spowodowała ona niewłaściwe leczenie albo opóźniła właściwe

leczenie, przyczyniając się do rozwoju choroby,

2) leczenia, w tym wykonania zabiegu operacyjnego,

3) zastosowania produktu leczniczego lub wyrobu medycznego.

Diagnozą - w rozumieniu art. 67a ust. 1 powołanej ustawy - jest rozpoznanie choroby na podstawie jej objawów, badania chorego, wywiadu lekarskiego i badań laboratoryjnych, jest to innymi słowy ocena stanu pacjenta wystawiona na podstawie badań i analiz, wykonywana za pomocą dostępnych metod diagnostycznych ${ }^{15}$. Za Z. Markiem podać można, że diagnoza musi być logicznym wnioskiem, zgodnym $\mathrm{z}$ zasadami logiki formalnej, niesprzecznym $\mathrm{z}$ wiedzą medyczną, wysnutym w oparciu o wyniki obserwacji, wnioski wynikające z przeprowadzonego wywiadu, wyniki przeprowadzonych badań i ewentualnych konsultacji ${ }^{16}$. Pomimo że polskie ustawodawstwo nie zawiera legalnej definicji pojęcia diagnozy, to pewnych wskazówek w tym zakresie dostarczają przepisy ustawy z dnia 5 grudnia 1996 r. o zawodach

12 S. Todd, Forty Years of Accident Compensation in New Zealand, Thomas M. Cooley Law Rewiev 2011, t. 28, nr 3, s. 189.

13 Tekst jednolity: Dz. U. z 2020 r. poz. 849.

14 Tekst jednolity: Dz. U. z 2020 r. poz. 295.

15 Z. Cnota, G. Gura, T. Grabowski, E. Kurowska, Zasady i tryb ustalania świadczeń/roszczeń (odszkodowania i zadośćuczynienia) w przypadku zdarzeń medycznych. Komentarz, 2016 [baza danych Legalis], Komentarz do art. 67a, teza 1.

16 Z. Marek, Błąd medyczny odpowiedzialność etyczno-deontologiczna i prawna lekarza, Kraków 2007, s. 67 . 
lekarza i lekarza dentysty ${ }^{17}$ oraz Kodeks Etyki Lekarskiej ${ }^{18}$ dotyczące obowiązków lekarza związanych z „badaniem” pacjenta (art. 42 ust. 1 ustawy o zawodach lekarza i lekarza dentysty art. 8 i art. 9 Kodeksu Etyki Lekarskiej) oraz przeprowadzenia „konsultacji” i „konsyliów” (art. 10 Kodeksu Etyki Lekarskiej oraz art. 35 ust. 1 i art. 37 ustawy o zawodach lekarza i lekarza dentysty). Odpowiedzialność za zdarzenia medyczne obejmuje także szkody powstałe w związku z leczeniem, w tym z zabiegiem operacyjnym (art. 67a ust. 1 pkt 2 ustawy o prawach pacjenta i Rzeczniku Praw Pacjenta). Leczeniem jest szereg czynności medycznych, wykonywanych przez osoby do nich uprawnione na podstawie odrębnych przepisów, zmierzających do poprawy stanu zdrowia pacjenta ${ }^{19}$. W nauce wskazuje się, że w zakresie leczenia zdarzenie medyczne może być wynikiem wyboru niewłaściwego sposobu leczenia również przy prawidłowej diagnozie ${ }^{20}$. Ustalenie zaś zakresu normowania art. 67a ust. 1 pkt 3 ustawy o prawach pacjenta i Rzeczniku Praw Pacjenta wymaga od interpretatora sięgnięcia poza przepisy tej ustawy ${ }^{21}$, tj. do art. 2 pkt 35-44 ustawy z dnia 20 maja 2010 r. o wyrobach medycznych ${ }^{22}$ oraz art. 2 pkt 29-33b i 35 ustawy z dnia 6 września 2001 r. - Prawo farmaceutyczne ${ }^{23}$. W doktrynie przy tym przeważają poglądy, zgodnie z którymi wykładnia art. 67a ust. 1 pkt 3 ustawy o prawach pacjenta i Rzeczniku Praw Pacjenta prowadzi do wniosku, że odpowiedzialność podmiotu leczniczego za zdarzenie medyczne w związku z zastosowaniem produktu leczniczego lub wyrobu medycznego sprowadza się do wypadków podania przez personel medyczny leku właściwego, lecz niezgodnie z wytycznymi aktualnej wiedzy medycznej, użycia leku czy też wyrobu medycznego niewłaściwego w stosunku do schorzenia, na które cierpi pacjent, czy użycia wyrobu medycznego niezgodnie z przeznaczeniem ${ }^{24}$. Powyższe oznacza, że

17 Tekst jednolity: Dz. U. z 2020 r. poz. 514.

18 Uchwała Nadzwyczajnego II Krajowego Zjazdu Lekarzy z dnia 14 grudnia 1991 z późń. zm.

19 Z. Cnota, G. Gura, T. Grabowski, E. Kurowska, Zasady ..., Komentarz do art. 67a, teza 3.

20 D. Karkowska, Ustawa o prawach pacjenta i Rzeczniku Praw Pacjenta. Komentarz, Warszawa 2012, s. 479.

21 W zakresie ustalenia znaczenia danego wyrażenia $\mathrm{z}$ wykorzystaniem definicji legalnej pochodzącej z innego aktu normatywnego zob. M. Zieliński, Wykładania prawa. Zasady, reguły, wskazówki, Warszawa 2008, s. 216-217 oraz \$ 9. rozporządzenia Prezesa Rady Ministrów w sprawie „Zasad techniki prawodawczej" z dnia 20 czerwca 2002 r., Dz. U. z 2002 r. Nr 100, poz. 908 (zob. szerzej G. Wierczyński, Komentarz do rozporzadzenia w sprawie „Zasad techniki prawodawczej”, w: Redagowanie i ogłaszanie aktów normatywnych. Komentarz, 2009 [baza danych LEX], Komentarz do $\$ 9$, teza 1).

22 Tekst jednolity: Dz. U. z 2020 r. poz. 186.

23 Tekst jednolity: Dz. U. z 2020 r. poz. 944.

24 H. Frąckowiak, Postępowanie przed Wojewódzką Komisją do spraw orzekania o zdarzeniach medycznych, Warszawa 2016, s. 28; D. Karkowska, J. Chojnacki, Postępowanie przed wojewódzka komisja do spraw orzekania o zdarzeniach medycznych, Warszawa 2014, s. 126 i 128. 
szkody, które podlegają naprawieniu w ramach omawianego systemu kompensacji, mogą wynikać z działania lub zaniechania personelu medycznego. Nie podlegają natomiast kompensacji szkody powstałe z samych właściwości leku czy wyrobu medycznego, za które podmiot leczniczy nie ponosi odpowiedzialności w omawianym postępowaniu.

Następna przesłanka odpowiedzialności związana jest z miejscem wyrządzenia szkody pacjentowi. Przepisy ustawy o prawach pacjenta i Rzeczniku Praw Pacjenta dotyczące dochodzenia roszczeń z tytułu zdarzeń medycznych znajdują zastosowanie bowiem jedynie do szkód powstałych w szpitalu (art. 67a ust. 1 przywołanej ustawy). Zgodnie z art. 2 ust. 1 pkt 9 ustawy o działalności leczniczej szpitalem jest zakład leczniczy (por. art. 2 ust. 1 pkt 14 tej ustawy), w którym podmiot leczniczy (zob. art. 4 tej ustawy) wykonuje działalność leczniczą w rodzaju świadczenia szpitalne (por. art. 2 ust. 1 pkt 11 ustawy o działalności leczniczej). Odpowiedzialność za szkody wynikające ze zdarzeń medycznych mogą lege non distinguente ponosić zarówno podmioty udzielające świadczenia szpitalne w sektorze publicznym, jak i prywatnym ${ }^{25}$. Zgodnie z poglądami doktryny założeniem ustawodawcy jest powszechność dostępu do pozasądowego systemu kompensacji szkód medycznych, który nie jest uzależniony od sposobu finansowania udzielanego świadczenia ${ }^{26}$.

Polski ustawodawca projektując postępowanie przed wojewódzką komisją, zdecydował się w art. 67a ust. 1 ustawy o prawach pacjenta i Rzeczniku Praw Pacjenta na przyjęcie, że jedynie te zdarzenia medyczne, które powstały na skutek działania albo zaniechania sprzecznego $\mathrm{z}$ aktualną wiedzą medyczną, mogą podlegać mechanizmowi kompensacyjnemu. W postępowaniu przed komisją konieczne jest więc ustalenie obiektywnej sprzeczności leczenia, diagnozy czy zastosowania produktów leczniczych oraz wyrobów medycznych z zasadami aktualnej wiedzy medycznej. Ustawodawca nie wymaga przy tym, co wynika z treści art. 67a ust. 1 ustawy o prawach pacjenta i Rzeczniku Praw Pacjenta, aby konieczne było wykazanie w postępowaniu przed komisją, który spośród członków personelu medycznego dopuścił się działania sprzecznego z wiedzą medyczną, czerpiąc w tym zakresie z uznanej na gruncie prawa cywilnego koncepcji winy anonimowej ${ }^{27}$.

25 E. Kowalewski, Ubezpieczenia pacjentów z tytułu zdarzeń medycznych-blaski i cienie, w: Kompensacja szkód wyniklych ze zdarzeń medycznych. Problematyka cywilnoprawna i ubezpieczeniowa, red. E. Kowalewski, Toruń 2011, s. 98.

26 H. Frąckowiak, Postępowanie..., s. 122.

27 Zob. przegląd poglądów i wypowiedzi judykatury: M. Pytlarz, Wina anonimowa jako podstawa odpowiedzialności deliktowej za szkody wyrządzone przy leczeniu, Prawo i Medycyna 2013, nr 1-2, s. $139-148$. 
Kwestia naruszenia zasad aktualnej wiedzy medycznej wymaga szerszego komentarza. Postępowanie niezgodne z zasadami aktualnej wiedzy medycznej obejmuje przypadki obiektywnego naruszenia przez lekarza lub personel medyczny zasad wykonywania zawodu. Obowiązkiem wszystkich członków personelu medycznego (lekarzy, diagnostów laboratoryjnych, pielęgniarek, położnych czy fizjoterapeutów) jest przede wszystkim podejmować działania diagnostyczne, lecznicze oraz rehabilitacyjne zgodnie $\mathrm{z}$ aktualną wiedzą medyczną oraz nieustannie się dokształcać, podążać za najnowszymi odkryciami w dziedzinie leczenia i diagnozy chorób. Powyższą tezę wspierają zarówno art. 4 ustawy o zawodach lekarza i lekarza dentysty, art. 6 ustawy o prawach pacjenta i Rzeczniku Praw Pacjenta, jak również normy zawarte w Kodeksie Etyki Lekarskiej ${ }^{28}$, które także mają wpływ na ocenę należytej staranności lekarzy ${ }^{29}$. Również w przepisach regulujących zasady wykonywania innych zawodów medycznych znaleźć można odwołanie do wykonywania zawodu zgodnie ze wskazaniami aktualnej wiedzy medycznej (zob. art. 11 ust. 1 i art. 61 ust. 1 ustawy z dnia 15 lipca 2011 r. o zawodach pielęgniarki i położnej ${ }^{30}$ czy art. 21 i art. 30 ustawy z dnia 27 lipca 2001 r. o diagnostyce laboratoryjnej ${ }^{31}$ ).

Medycyna, jak niemal żadna inna dziedzina wiedzy, podlega dynamicznemu rozwojowi ${ }^{32}$. Metody postępowania jeszcze niedawno uważane za skuteczne, w miarę nowych odkryć naukowych okazują się mniej efektywne lub całkiem nieużyteczne ${ }^{33}$. Stąd też przyznać należy za Sądem Najwyższym, że nauka medycyny „nie jest dana raz na zawsze" i nie posiada stałych, niezmiennych reguł ${ }^{34}$. Dlatego też z obowiązkiem stosowania aktualnej wiedzy medycznej przez przedstawicieli zawodów medycznych skorelowany jest nakaz nieustannego dokształcania się (zob. np.

28 Zob. w szczególności art. 6 zd. 2, art. 56 ust. 1 czy art. 57 Kodeksu Etyki Lekarskiej.

29 Ocena należytej staranności zgodnie z poglądami wyrażonymi w judykaturze oraz nauce odbywa się również przez pryzmat norm deontologicznych wyrażonych w Kodeksie Etyki Lekarskiej (zob. wyrok SN z dnia 13 lutego 2004 r., IV CK 40/03, LEX nr 151636). Regulacje Kodeksu Etyki Lekarskiej prawnie sankcjonowane są przez art. 4 ustawy o zawodach lekarza i lekarza dentysty, a także art. 5 pkt 1 ustawy z dnia 2 grudnia 2009 r. o izbach lekarskich, tekst jednolity: Dz. U. z 2019 r. poz. 965 (zob. szerzej wyrok TK z dnia 23 kwietnia 2008 r., SK 16/07, Dz. U. z 2008 r. Nr 38, poz. 342; M. Sośniak, Glosa do orzeczenia Sądu Najwyższego z dnia 7 stycznia 1966, sygn. akt I CR 369/65, OSP 1966, nr 12, poz. 278).

30 Tekst jednolity: Dz. U. z 2020 r. poz. 562.

31 Tekst jednolity: Dz. U. z 2020 r. poz. 2061.

32 Ustawa o zawodach lekarza i lekarza dentysty. Komentarz, red. E. Zielińska, 2014 [baza danych LEX], Komentarz do art. 4, teza 5.

33 Ustawa o zawodach lekarza..., Komentarz do art. 4, teza 5; M. Boratyńska, P. Konieczniak, Prawa pacjenta, Warszawa 2001, s. 172-173; M. Sośniak, Cywilna odpowiedzialność lekarza, Warszawa 1989, s. 71.

34 Wyrok SN z dnia 25 marca 1954 r., II K 172/54, niepubl., cyt. za: D. Karkowska, Ustawa..., s. 106. 
art. 18 ust. 1 ustawy o zawodach lekarza i lekarza dentysty). Obowiązek ten formułowany wobec przedstawicieli wszystkich zawodów medycznych wyklucza ich ewentualną obronę w procesie czy postępowaniu przed komisją zmierzającą do wykazania, że określonej wiedzy nie nabyli oni w trakcie studiów wyższych ${ }^{35}$. Nakaz stosowania aktualnej wiedzy medycznej obejmuje nie tylko czynności diagnostyczne oraz lecznicze, ale również stosowanie wyrobów medycznych oraz produktów leczniczych ${ }^{36}$. Ocena spełnienia przez lekarza wymogu działania zgodnie z wiedzą medyczną odbywać się zaś będzie zawsze przez pryzmat pewnego obiektywnego wzorca postępowania $^{37}$, który musi być ulokowany $\mathrm{w}$ danym miejscu, czasie i warunkach ${ }^{38}$, w których świadczenie jest udzielane. Wobec dynamicznego postępu nauk medycznych konieczne staje się tworzenie standardów postępowania opartych na aktualnym stanie wiedzy medycznej i naukowych dowodach (Evidence Based Medicine) ${ }^{39}$. Przykładem takich standardów są rozporządzenia Ministra Zdrowia wydawane na podstawie delegacji ustawowej zawartej w art. 22 ust. 5 ustawy o działalności leczniczej. Obecnie na podstawie przedmiotowej delegacji wydanych zostało siedem rozporządzeń dotyczących m.in. opieki zdrowotnej w dziedzinie patomorfologii ${ }^{40}$, opieki okołoporodowej ${ }^{41}$ czy opieki nad osobami podejrzanymi o zakażenie albo zakażonymi wirusem SARS-CoV-2 $2^{42}$.

Krąg podmiotów uprawnionych do dochodzenia żądania ustalenia zdarzenia medycznego został określony $\mathrm{w}$ art. 67b ust. 1 ustawy o prawach pacjenta i Rzeczniku Praw Pacjenta, który przyznaje to uprawnienie pacjentowi, a w przypadku jego śmierci, także jego spadkobiercom. Zgodnie z art. 3 ust. 1 pkt 4 powołanej wyżej ustawy pacjentem jest osoba zwracająca się o udzielenie świadczeń zdrowotnych lub

35 R. Kędziora, Odpowiedzialność karna lekarza w związku z wykonywaniem czynności medycznych, Warszawa 2009, s. 112-113.

36 Wyrok SA w Warszawie z dnia 4 marca 2015 r., I ACa 515/14, Legalis nr 1219146.

37 M. Sośniak, Cywilna odpowiedzialność..., s. 105-108.

38 Tamże, s. 107.

39 Ustawa o zawodach lekarza i lekarza dentysty. Komentarz, red. E. Zielińska, Warszawa 2008, s. 65. Zob. też: M. Boratyńska, Wolny wybór. Granice i gwarancje prawa pacjenta do samodecydowania, Warszawa 2012, s. 229 i nast.; B. Kamiński, Na marginesie reformy, standardów medycznych i Europejskiej Konwencji Bioetycznej - refleksje klinicysty, Prawo i Medycyna 1999, nr 3, s. 109 czy T. Dukiet-Nagórska, O potrzebie wypracowania standardów postępowania dotyczacych niepodjęcia terapii i jej zaprzestania, Prawo i Medycyna 2008, nr 2, s. 24-25.

40 Rozporządzenie Ministra Zdrowia z dnia 18 grudnia 2017 r. w sprawie standardów organizacyjnych opieki zdrowotnej w dziedzinie patomorfologii, Dz. U. z 2017 r. poz. 2435.

41 Rozporządzenie Ministra Zdrowia z dnia 16 sierpnia 2018 r. w sprawie standardu organizacyjnego opieki okołoporodowej, Dz. U. z 2018 r. poz. 1756.

42 Rozporządzenie Ministra Zdrowia z dnia 8 października 2020 r. w sprawie standardu organizacyjnego opieki zdrowotnej nad pacjentem podejrzanym o zakażenie lub zakażonym wirusem SARS-CoV-2, Dz. U. z 2020 r. poz. 1749. 
korzystająca ze świadczeń zdrowotnych udzielanych przez podmiot je świadczący lub osobę wykonującą zawód medyczny. Nieistotne z punktu widzenia przywołanej definicji jest, czy pacjent korzysta z publicznej czy niepublicznej służby zdrowia oraz czy posiada albo nie uprawnienia do świadczeń opieki zdrowotnej finansowej ze środków publicznych ${ }^{43}$. Pacjentem jest także obcokrajowiec bez względu na podstawę finansowania udzielanych mu świadczeń zdrowotnych ${ }^{44}$.

O ile przyznanie uprawnienia do dochodzenia żądania ustalenia zdarzenia medycznego przez pacjenta, jako podmiotu bezpośrednio poszkodowanego, jest bezdyskusyjne, to przyznanie tego uprawnienia spadkobiercy budzi w nauce wątpliwości ${ }^{45}$. Zgodnie $\mathrm{z}$ art. $922 \$ 1$ K.c. ${ }^{46} \mathrm{z}$ chwilą śmierci spadkodawcy wszelkie jego prawa i obowiązki majątkowe przechodzą na jedną lub kilka osób. Przy czym spadkobiercą może być tylko żyjąca w chwili otwarcia spadku osoba fizyczna, istniejąca osoba prawna lub jednostka organizacyjna $z$ art. $33^{1}$ K.c. (art. $927 \$ 1$ K.c.). Krąg spadkobierców, którzy w przypadku śmierci pacjenta mogą wnieść wniosek o ustalenie zdarzenia medycznego, obejmuje lege non distinguende zarówno podmioty prawa cywilnego dziedziczące z ustawy (art. 931 K.c. i nast.), jak i z testamentu (art. 941 K.c. i nast. $)^{47}$.

\section{Nowozelandzki punkt odniesienia}

We wrześniu 1966 r. ${ }^{48}$ w Nowej Zelandii powołana została Komisja do Spraw Reformy Systemu Wynagradzania Szkód na Osobie (Royal Commision of Inquiary on Compensation for Personal Injury) zwana - od imienia jej przewodniczące-

43 D. Karkowska, Ustawa..., s. 76, D. Karkowska, J. Chojnacki, Postępowanie..., s. 143.

44 H. Frąckowiak, Postępowanie..., s. 107.

45 M. Białkowski, Zmiany w Ustawie o prawach pacjenta i Rzeczniku Praw Pacjenta. Kilka uwag o mechanizmie uzyskiwania odszkodowania lub zadośćuczynienia w postępowaniu przed wojewódzkimi komisjami do spraw orzekania o zdarzeniach medycznych, Przegląd Prawniczy Uniwersytetu im. Adama Mickiewicza 2012, nr 1, s. 143-144 wraz z powołaną tam literaturą.

46 Ustawa z dnia 23 kwietnia 1964 r. - Kodeks cywilny, tekst jednolity: Dz. U. z 2020 r. poz. 1740 (dalej: K.c.).

$47 \quad$ K. Bączyk-Rozwadowska, Odpowiedzialność cywilna..., s. 345.

48 D.L. Mathieson, Royal Commission of Inquiry: Compensation for Personal Injury in New Zealand, The Modern Law Review 1968, t. 31, nr 5, s. 544. Zob. bardzo szeroko nakreślone tło historyczne w: A. Biały, Accident Compensation System - jako przykład systemu naprawienia szkody na osobie w Nowej Zelandii - wybrane zagadnienia w ujęciu historycznym, Studia Prawnicze KUL 2019, nr 3 (79), s. 7-17 i taż, Czyny niedozwolone w Nowej Zelandii. Accident Compensation System, Lublin 2020, s. 181-199. 
go Owena Woodhouse'a - Komisją Woodhouse'a ${ }^{49}$. W Raporcie Woodhouse'a ${ }^{50}$ z dnia 20 maja 1968 r. ${ }^{51}$ przedstawiona została propozycja modelu no-fault opartego o pięć zasad ${ }^{52}$, tj. powszechnej kompensacji obejmującej wszystkie podmioty (community responsibility), powszechnego dostępu do świadczeń (comprehensive entitlement), przywrócenia stanu sprzed powstania szkody (complete rehabilitation), pełnej kompensaty doznanej szkody (real compensation) i efektywnego ukształtowania procedur kompensacyjnych (administrative efficiency) ${ }^{53}$. System oparty o wyżej wymienione zasady wszedł w życie z dniem 1 kwietnia 1974 r. $^{54}$ (The Accident Compensation $A c t^{55}$ ), obecnie oparty jest o przepisy Injury Prevention, Rehabilitation, and Compensation Act 2001 (Public Act 2001 No 49) ${ }^{56}$ (dalej: IPRCA), który wszedł w życie 1 kwietnia 2002 r. ${ }^{57}$ Wprowadzony system - kilkukrotnie istotnie nowelizowany $^{58}$ - ma charakter kompleksowy i obejmuje nie tylko szkody powstałe przy leczeniu, ale także wypadki przy pracy czy szkody powstałe na skutek wypadków drogowych ${ }^{59}$.

Z punktu widzenia celu pracy istotne jest, że od 1 lipca $1992 \mathrm{r}^{60} \mathrm{w}$ ramach omawianego systemu możliwe stało się rekompensowanie szkód powstałych

49 A. Biały, Accident..., s. 10; S. Todd, Forty..., s. 190; A.M. Farrell, S. Devaney, A. Dar, No-fault compensation schemes for medical injury: A review, Scottish Government Social Research 2010, s. 14.

50 Szczegółowo na temat prac Komisji zob. S. Todd, Forty..., s. 190-192.

51 A. Biały, Accident..., s. 10.

52 P. McKenzie, The compensation scheme no one asked for: the origins of ACC in New Zealand, Victoria University of Wellington Law Review 2003, t. 34, s. 196-198; A Biały, Czyny niedozwolone..., s. 185; K. Bączyk, Nowozelandzki model odpowiedzialności za szkody wyrządzone przy leczeniu, Prawo i Medycyna 2004, nr 1, s. 69.

53 C.M. Flood, New Zealand's No-Fault Accident Compensation Scheme: Paradise or Panacea?, Health Law Review 2000, t. 8, nr 3, s. 3; S. Todd, Forty..., s. 191.; R. Upperton, A truly no-fault approach to treatment injury cover in accident compensation [dysertacja], Faculty of Law Victoria University of Wellington, Wellington 2013, s. 9-11.

54 S. Todd, Forty..., s. 189, 33; K. Oliphant, Accident Compensation in New Zealand, s. 3-5, https:// www.courdecassation.fr/IMG/File/pdf_2006/05-12-2006_assurance/05-12-06_ken_oliphant-en. pdf; K. Bączyk, Nowozelandzki..., s. 69.

55 Accident Compensation Act 1972 (1972, No 43), http://www.nzlii.org/nz/legis/hist_act/aca19721972 n43231/ [dostęp: 17.03.2021 r.].

56 Opublikowany na stronach Parliamentary Counsel Office: http://www.legislation.govt.nz/act/public/2001/ 0049/latest/DLM99494.html [dostęp: 26.10.2020 r.].

57 A.M. Farrell, S. Devaney, A. Dar, No-fault..., s. 14.

58 A. Biały, Accident..., s. 9-10. W odniesieniu do zmian w systemie w okresie od 1974 do $2001 \mathrm{r}$. zob. A. Duffy, The The Common-Law Response to the Accident Compensation Scheme, Victoria University of Wellington Law Review 2003, t. 34, s. 367-384. Zob. też: S. Todd, Forty ..., s. 193-198.

59 C. Brown, Deterrence in tort and no fault: The New Zealand experience, California Law Review 1985, t. 73 , nr 3, s. 693 i nast.

60 W odniesieniu do okresu 1982-1992 zob. K. Bączyk, Nowozelandzki..., s. 72-73. 
z wypadków medycznych (medical misadventure) ${ }^{61}$, które dzieliły się na błędy medyczne, tj. zdarzenia wynikającego $\mathrm{z}$ niedbalstwa ${ }^{62}$ (medical errors), oraz wypadki medyczne (medical mishap), tj. szkody powstałe na skutek prawidłowego leczenia, którego następstwa doprowadziły do powstania poważnej szkody lub prawdopodobieństwo ich wystąpienia opisane w literaturze było niskie (wynosiło mniej niż 1\% przypadków, ang. rare) i wyjątkowo dolegliwe (np. skutkujące śmiercią czy hospitalizacją powyżej $14 \mathrm{dni}$, ang. severe) ${ }^{63}$. Do czasu reformy systemu w 2005 r. 86\% rozpatrywanych spraw w ramach systemu nowozelandzkiego miało charakter wypadku medycznego, a jedynie $14 \%$ stanowiło błąd medyczny ${ }^{64}$. W nauce podnoszono, że taki system kompensacji nie był właściwy, faktycznie bowiem prowadził w części do utrzymania systemu opartego na winie (konieczność stwierdzenia niedbalstwa przy medical error ${ }^{65}$. Wymóg ustalenia winy sprawcy szkody (poprzez wymóg udowodnienia naruszenia przez lekarza standard of care and skill) ${ }^{66}$ oraz używanie przez ustawodawcę zbyt niedookreślonych pojęć stało się przyczyną zmian w przepisach ${ }^{67}$. Podnoszono bowiem, że system ten w odniesieniu do szkód medycznych nie spełnia pokładanych w nim oczekiwań, ponieważ jest nieefektywny, arbitralny i powodujący narastanie konfliktów między stronami sporu z uwagi na konieczność poszukiwania winnego wyrządzenia szkody ${ }^{68}$. Krytyka doprowadziła w 2005 r. do reformy, która nadała obecny kształt nowozelandzkiemu systemowi w zakresie odpowiedzialności za szkody wyrządzone przy leczeniu ${ }^{69}$. W efekcie podjętych prac zdecydowano się oprzeć go na założeniu, że powinien on umożliwiać naprawienie każdej choćby niezamierzonej szkody powstałej przy leczeniu (odrzucono m.in. koncepcję badania możliwości zapobieżenia szkodzie jako przesłanki odpowiedzialności $)^{70}$.

61 K. Bączyk, Nowozelandzki..., s. 73-76.

62 R. Upperton, A truly ..., s. 14-15; K. Oliphant, Accident..., s. 11.

63 S. Todd, Forty..., s. 201; A.M. Farrell, S. Devaney, A. Dar, No-fault..., s. 16; R. Upperton, A truly..., s. 4 i 15; K. Oliphant, Accident..., s. 11. Zob. też orzecznictwo powołane w: K. Bączyk, Nowozelandzki..., s. 74; M. Serwach, Ochrona ubezpieczeniowa pacjentów przed negatywnymi skutkami leczenia, Kraków 2018, s. 119.

64 K. Bączyk-Rozwadowska, Odpowiedzialność cywilna..., s. 229.

65 A.M. Farrell, S. Devaney, A. Dar, No-fault..., s. 16-17.

66 Zob. K. Bączyk, Nowozelandzki..., s. 73-74 wraz z powołanym tam orzecznictwem.

67 A.M. Farrell, S. Devaney, A. Dar, No-fault..., s. 16-17.

68 R. Upperton, A truly..., s. 4.

69 Szczegółowo w odniesieniu do zarzutów dotyczących dotychczasowego systemu zob. R. Upperton, A truly..., s. 4 i 15-16; K. Oliphant, Accident..., s. 10.

$70 \quad$ R. Upperton, A truly ..., s. 16-17. 
Obecnie $^{71} \mathrm{w}$ miejsce medical misadvanture wprowadzone zostało pojęcie treatment injury (section 32.1 IPRCA) ${ }^{72}$. Przez termin ten przepisy IPRCA rozumieją szkodę powstałą w związku z udzielaniem świadczeń leczniczych przez każdy podmiot profesjonalny, mający uprawnienia do udzielania tego typu świadczeń (registered health profesional). Szkoda, aby mogła podlegać naprawieniu w ramach omawianego systemu, musi powstać $\mathrm{w}$ związku z leczeniem i przy tym nie może stanowić zwykłej (możliwej do przewidzenia) konsekwencji podjętego leczenia (np. blizna po leczeniu operacyjnym czy nacięcie skóry dokonane przez chirurga w związku z operacją) ${ }^{73}$. Przy ocenie tej ostatniej przesłanki bierze się pod uwagę głównie stan zdrowia pacjenta oraz stan wiedzy medycznej w chwili udzielania mu pomocy medycznej (section 32.1 a-c IPRCA) ${ }^{74}$. Zgodnie z poglądami doktryny pojęcie treatment injury zostało tak skonstruowane przez nowozelandzkiego ustawodawcę, by obejmować całość szkód wyrządzonych przy leczeniu zarówno możliwych do przewidzenia i zapobieżenia, jak i tych zupełnie nieprzewidywalnych ${ }^{75}$. Nie jest przy tym konieczną przesłanką, by szkoda powstała w trakcie samego leczenia ${ }^{76}$.

Przez samo pojęcie leczenia (treatment) rozumie się zgodnie z IPRCA section 33.1 a-h działania z zakresu profilaktyki, diagnozy czy leczenia, zarówno w zakresie decyzji dotyczącej sposobu leczenia, jak i zaniechania jego podjęcia ${ }^{77}$. Pojęcie to obejmuje także szkody związane z podjęciem leczenia bez poinformowanej zgody pacjenta lub wyrządzone w związku ze stosowaniem wadliwego lub niesprawnego sprzętu medycznego, protez czy implantów, niezależnie od tego, czy szkoda powstała w trakcie podejmowanej interwencji medycznej, czy już w trakcie korzystania ze sprzętu medycznego ( $\mathrm{z}$ wyłączeniem szkód powstałych na skutek naturalnego zużycia sprzętu $)^{78}$. Zaznaczyć przy tym należy, że sam fakt, iż leczenie nie odniosło zamierzonego celu (nie doprowadziło do wyleczenia pacjenta), nie stanowi o zaistnieniu treatment injury (section 32.3 IPRCA) ${ }^{79}$. Pojęcie treatment injury obejmuje

\footnotetext{
71 W odniesieniu do obecnego kształtu systemu i powiązania go z system powszechnych ubezpieczeń zob. też M. Serwach, Ochrona ubezpieczeniowa..., s. 115-131.

72 S. Todd, Forty..., s. 202; M. Serwach, Ochrona ubezpieczeniowa..., s. 120-121.

73 R. Upperton, A truly..., s. 21-24.

74 S. Todd, Forty..., s. 202; A.M. Farrell, S. Devaney, A. Dar, No-fault..., s. 19.

75 A.M. Farrell, S. Devaney, A. Dar, No-fault..., s. 17-18.

76 J. Manning, Treatment injury and medical misadventure, w: Medical Law in New Zealand, red. P. Skegg i R. Paterson, Wellington 2006, s. 698-699.

77 R. Upperton, A truly..., s. 19-20; S. Todd, Forty..., s. 202; A. Biały, Czyny niedozwolone..., s. 210.

78 R. Upperton, A truly..., s. 19-20; M. Serwach, Ochrona ubezpieczeniowa..., s 121.

79 S. Todd, Forty..., s. 202; R. Upperton, A truly..., s. 31-32.
} 
także szkody wyrządzone w związku z badaniami klinicznymi (clinical trial) (section 32.4-6 IPRCA).

Przepisy IPRCA zawierają - oprócz regulacji dotyczącej samego treatment injury - pewien automatyczny mechanizm kompensacyjny (zob. section 20.2 IPRCA). Jeżeli bowiem in casu dojdzie do naprawienia szkody na osobie i następnie poszkodowany dozna kolejnej szkody wynikającej z leczenia związanego z doznaną wcześniej pierwotną szkodą, to druga (dalsza) szkoda podlega automatycznej kompensacji. Innymi słowy omawiane rozwiązanie można porównać w skutkach do ustalenia w polskim porządku prawnym przez sąd odpowiedzialności za następstwa szkody na przyszłośćs ${ }^{80}$. Szkodę taką traktuje się w zależności od okoliczności jako nową szkodę wymagającą naprawienia albo konsekwencję wcześniejszego leczenia, które doprowadziło do pogorszenia stanu zdrowia ${ }^{81}$. Jeżeli jednak pierwotna szkoda nie została naprawiona w oparciu o przepisy IPRCA, to druga szkoda, aby podlegać kompensacji, musi zostać oceniona zgodnie z kryteriami przyjętymi w section 32.1 IPRCA $^{82}$.

Pomimo tak szerokiego zakresu kompensacji nie wszystkie uszczerbki powstałe przy leczeniu podlegają kompensacji. Section 32.2 IPRCA wymienia trzy przesłanki negatywne otrzymania rekompensaty doznanego przy leczeniu uszczerbku ${ }^{83}$.

Pierwsze wyłączenie odpowiedzialności dotyczy szkód powstałych w przeważającej części z przyczyn leżących (substantially caused) w organizmie poszkodowanego (underlying health condition) (section 32.2 a IPRCA) ${ }^{84}$. Powyższe wyłączenie obejmuje sytuacje, w których nie jest możliwe ustalenie, że szkoda powstała w związku z podjętym leczeniem. Przesłanką bowiem odpowiedzialności w nowozelandzkim systemie pozostaje istnienie związku przyczynowego (direct causal link) pomiędzy leczeniem a szkodą ${ }^{85}$. Gdy więc leczenie lub jego zaniechanie nie miało wpływu na powstanie lub rozwinięcie się choroby, odpowiedzialność jest wyłączona. Jeśli szkoda pozostaje częściowo w związku z leczeniem, częściowo zaś ze stanem zdrowia pacjenta, konieczne jest rozstrzygnięcie, który czynnik miał przeważający wpływ na jej powstanie ${ }^{86}$.

80 Zob. uchwała Składu Siedmiu Sędziów Sądu Najwyższego - Izba Pracy i Ubezpieczeń Społecznych zasada prawna z dnia 17 kwietnia 1970 r., III PZP 34/69, OSNCP 1970, nr 12, poz. 217; uchwała Sądu Najwyższego - Izba Cywilna z dnia 24 lutego 2009 r., III CZP 2/09, OSNC 2009, nr 12, poz. 168.

81 A.M. Farrell, S. Devaney, A. Dar, No-fault..., s. 18.

82 J. Manning, Treatment injury..., s. 708.

83 Zob. też R. Upperton, A truly..., s. 20-21; S. Todd, Forty..., s. 202; A Biały, Czyny niedozwolone..., s. 209.

84 Zob. szeroko w zakresie zastosowania tego wyłączenia: R. Upperton, A truly ..., s. 27-30.

85 A.M. Farrell, S. Devaney, A. Dar, No-fault..., s. 18.

86 J. Manning, Treatment injury..., s. 709. 
Drugie wyłączenie odpowiedzialności odszkodowawczej (section 32.2 b IPRCA) dotyczy szkód stanowiących wyłączne następstwo podziału środków w ramach systemu ochrony zdrowia. Gdyby więc szkoda powstała w związku z brakami organizacyjnymi albo niedostatecznym finansowaniem profilaktyki albo leczenia danego schorzenia, to fakt ten per se nie mógłby stanowić podstawy roszczenia (problem tzw. waiting list, pacjentów oczekujących na zabieg czy braku refundacji określonych leków) ${ }^{87}$. Jednak w przypadku, gdyby podział środków stanowił jedną z kilku konkurencyjnych przyczyn powstania szkody, wówczas możliwe byłoby przyjęcie odpowiedzialności opartej na konstrukcji treatment injury, przy spełnieniu pozostałych przesłanek odpowiedzialności i jednocześnie przy rozstrzygnięciu, jaki wpływ na uszczerbek miały jego pozostałe przyczyny ${ }^{88}$.

Trzecim wyłączeniem uregulowanym w section 32.2 c IPRCA jest sytuacja, w której szkoda powstaje na skutek opóźnienia bądź niepodjęcia leczenia przez pacjenta, który został należycie poinformowany o swoim stanie zdrowia, o koniecznych środkach leczenia oraz o skutkach braku bądź opóźnienia leczenia. Również i to wyłączenie należy uznać za uzasadnione z uwagi na - będące konsekwencją poszanowania autonomii woli pacjenta - przejście ryzyka wyrządzenia szkody na pacjenta w przypadku, gdy pomimo należytego poinformowania odmawia on leczenia ${ }^{89}$.

Przepisy IPRCA nie obejmują także, poza nielicznymi wyjątkami ${ }^{90}$, szkód w postaci zakłócenia czynności psychicznych i rozstroju zdrowia psychicznego oraz szkód wyrządzonych dziecku poczętemu jednak martwo urodzonemu (nie wyłącza to jednak kompensacji szkód na osobie wyrządzonych matce dziecka) ${ }^{91}$. Zgodnie $\mathrm{z}$ poglądem wyrażonym $\mathrm{w}$ judykaturze nowozelandzkiej za treatment injury nie może być także uważane urodzenie dziecka $\mathrm{w}$ wyniku wadliwego przeprowadzenia procesu sterylizacji zarówno wobec matki, jak i ojca ${ }^{92}$.

W nowozelandzkim systemie świadczenia odszkodowawczego dochodzić może bezpośrednio poszkodowany pacjent (section 32.1 IPRCA), a także osoba uczestnicząca w badaniach klinicznych (section 32.4 IPRCA w zw. secion 32.6 IPRCA i section 32.5 IPRCA). Nowozelandzki ustawodawca przy tym odmiennie niż ma to miejsce w Polsce uregulował problematykę dochodzenia świadczenia przez osoby, którym szkoda nie została wyrządzona bezpośrednio w związku z leczeniem. I tak

\footnotetext{
87 R. Upperton, A truly..., s. 30.

88 J. Manning, Treatment injury..., s. 714.

89 Tamże, s. 715.

90 S. Todd, Forty..., s. 205.

91 A.M. Farrell, S. Devaney, A. Dar, No-fault..., s. 20.

92 Tamże.
} 
np. w przypadku szkody wyrządzonej w związku z infekcją doznaną przez pacjenta wyrównania uszczerbku w tym zakresie mogą dochodzić także poszkodowani, którzy nie zarazili się w szpitalu, a w związku z kontaktem z wcześniej zarażonym pacjentem (jego dzieci, współmałżonek, partner lub inna osoba trzecia) (section 32.7 IPRCA $)^{93}$. Przepisy IPRCA umożliwiają również naprawienie szkody powstałej w związku ze śmiercią pacjenta (np. poprzez pokrycie kosztów pogrzebu - Schedule 1, section 64 IPRCA, zapłatę tzw. survivor's grant (swoistego zryczałtowanego odszkodowania) - Schedule 1, section 65 IPRCA, renty zmierzającej do zrekompensowania zarobku zmarłego małżonka - Schedule 1, section 66 IPRCA czy renty na rzecz dziecka oraz innej osoby pozostającej pod opieką zmarłego (other dependent) - Schedule 1, section 71). Jednak lektura wyżej wymienionych przepisów prowadzi do wniosku, że głównym celem jest naprawienie uszczerbku u tych osób, które faktycznie pozostają bliskie zmarłemu. W odniesieniu bowiem do małżonka i partnera (osoba pozostająca de facto w związku ze zmarłym - section 18A.1 IPRCA) wyłączają one możliwość ubiegania się o świadczenie odszkodowawcze, gdy małżonek albo partner nie mieszkał (poza wypadkami uzasadnionymi np. zdrowotnie - section 18.3 i 18A.3 IPRCA) ze zmarłym pacjentem i nie wspierał go finansowo (odpowiednio section 18.2 i 18A.2 IPRCA). Również w przypadku dzieci czy innych osób pozostających pod opieką zmarłego przepisy nowozelandzkie nie ograniczają się do oceny istniejącego stosunku rodzinnoprawnego. Przepisy bowiem w omawianym zakresie umożliwiają zaliczenie do grona np. dzieci zmarłego osoby, które ten „traktował jak swoje dzieci” (acted as a parent of the child) (section 6.1.child.(c).(ii) IPRCA).

\section{Zakończenie}

Przechodząc do oceny przyjętych w Polsce i Nowej Zelandii rozwiązań, zacząć należy od stwierdzenia, że polski ustawodawca nie zastosował się do podstawowego założenia systemu typu no-fault, jakim jest całkowite oderwanie odpowiedzialności od zasady winy. W systemie nowozelandzkim wyczerpanie definicji treatment inju-

93 R. Upperton, A truly..., s. 19; M. Serwach, Ochrona ubezpieczeniowa..., s. 122. Por. z wyrokiem SA w Poznaniu z dnia 9 maja 2002 r., ACa 221/02, LEX nr 84450. De lege ferenda należy postulować wprowadzenie możliwości rekompensaty tego typu uszczerbków również w postępowaniu przed komisją i to niezależnie - jak ma to miejsce w powołanym orzeczeniu - od ewentualnej winy w nieudzieleniu pacjentowi pełnej informacji przez podmiot leczniczy co do ryzyka zarażenia członków rodziny i środków prewencyjnych, które może on zastosować w celu jego uniknięcia. 
ry przez określone zdarzenie szkodzące stanowi wystarczającą podstawę do dochodzenia świadczenia odszkodowawczego bez konieczności badania przesłanki winy. Poszkodowany nie jest w tym systemie zobowiązany do wykazywania, że szkoda powstała ze względu na naruszenie jakichkolwiek reguł wykonywania zawodu czy aktualnej wiedzy medycznej. Wystarczające jest jedynie wykazanie związku pomiędzy leczeniem a powstałym uszczerbkiem wyczerpującym omówione wyżej znamiona treatment injury ${ }^{94}$. Warto przy tym zwrócić uwagę, że system nowozelandzki przeszedł długą drogę w zakresie kompensacji szkód medycznych, początkowo opierając się m.in. na winie (wynikające $\mathrm{z}$ zaniedbania medical error jako podstawa naprawienia szkody). Nowozelandzki ustawodawca potrafił wyciągnąć wnioski z przyjętego założenia i choć system ten nadal niekiedy poddawany jest krytyce jako niezupełny ${ }^{95}$, to przytoczone na wstępie dane świadczą o tym, że spełnia swoje zadanie. W polskim systemie zaś pacjent albo jego spadkobierca nadal - pomimo doświadczeń zagranicznych systemów - zobowiązani są do uprawdopodobnienia przy wykorzystaniu dowodu $\mathrm{z}$ opinii specjalisty (art. 67i ust. $7 \mathrm{i}$ art. 67o ustawy o prawach pacjenta i Rzeczniku Praw Pacjenta w zw. z art. 280-289 K.p.c. $\left.{ }^{96}\right)$, że w konkretnym wypadku doszło do naruszenia zasad wiedzy medycznej. Fakt, iż w postępowaniu przed komisją nie jest konieczne przypisanie naruszenia konkretnemu sprawcy szkody czy udowodnienie jego winy w znaczeniu subiektywnym ${ }^{97}$, nie wpływa znacząco na poprawę sytuacji poszkodowanego w postępowaniu przed komisją w porównaniu z postępowaniem sądowym. Od dawna bowiem w polskim orzecznictwie odpowiedzialność deliktowa w przypadku szkód medycznych uległa daleko idącej obiektywizacji (również dzięki szerokiemu korzystaniu z tzw. kon-

94 W systemie nowozelandzkim ustalona została reguła, zgodnie z którą w celu wykazania istnienia związku przyczynowego poszkodowany jest zobowiązany do ustalenia w postępowaniu dowodowym, że określona przyczyna szkody, z której pacjent wywodzi roszczenie, jest bardziej prawdopodobna od innej (balance of probabilities). Poszkodowany przy tym może korzystać z licznych - wypracowanych w praktyce - udogodnień w wykazaniu zachodzenia związku przyczynowego, np. możliwe jest ustalenie zachodzenia związku przyczynowego w oparciu o dane statystyczne zgromadzone w literaturze fachowej dotyczące szansy wystąpienia określonego powikłania (inferential reasoning), wnioskowanie o istnieniu związku przyczynowego w oparciu o znaczny stopień jego prawdopodobieństwa (bridging the evidentiary gap by drawing a robust inference of causation) czy traktowanie wysokiego ryzyka powstania szkody jako wystarczającego do ustalenia związku przyczynowego (treating a material increase in risk as sufficient proof of causation) (zob. szeroko J. Manning, Factual causation in medical negligence, The Journal of Law Medicine 2007, nr 15 (3), s. 337-343).

95 S. Todd, Forty..., s. 203.

96 Ustawa z dnia 17 listopada 1964 r. - Kodeks postępowania cywilnego, tekst jednolity: Dz. U. z 2020 r. poz. 1575 (dalej: K.p.c.).

97 Zob. szeroko przedstawiane stanowiska w tym przedmiocie w uzasadnieniu wyroku TK z dnia 11 marca 2014 r., K 6/13, Dz. U. z 2014 r. poz. 372; OTK-A 2014, nr 3, poz. 29. 
cepcji winy anonimowej $)^{98}$. Samo zdarzenie medyczne zaś w konsekwencji to pojęcie bardzo zbliżone do stosowanego w orzecznictwie pojęcia błędu medycznego ${ }^{99}$. Faktycznie więc jedna z największych bolączek procesu odszkodowawczego (obok konieczności wykazania adekwatnego związku przyczynowego ${ }^{100}$ ) nie została z polskiego systemu eradykowana.

Krytycznie odnieść należy się również do ograniczenia możliwości rekompensaty szkody w polskim systemie jedynie do uszczerbków doznanych w szpitalu (art. 67a ust. 2 ustawy o prawach pacjenta i Rzeczniku Praw Pacjenta). Bez względu na to, gdzie została szkoda wyrządzona ani w związku z jakiego typu procedurami medycznymi, poszkodowany powinien mieć możliwość naprawienia jej w postępowaniu przed komisją. Pozasądowy system, podobnie jak ma to miejsce w systemie nowozelandzkim (gdzie rekompensowana szkoda może być wyrządzona przez any registered health profesional), powinien mieć charakter kompleksowy i obejmować wszelkie szkody wyrządzone w następstwie zdarzeń medycznych, bez względu na formę organizacyjno-prawną podmiotu leczniczego. Z aprobatą należy jednak odnieść się do braku rozróżniania przez polskiego ustawodawcę sytuacji prawnej poszkodowanego $\mathrm{z}$ uwagi na wyrządzenie szkody $\mathrm{w}$ publicznym czy też prywatnym szpitalu podmiotu leczniczego. De lege ferenda postulować należałoby również poszerzenie zakresu szkód, które podlegają rekompensacie w postępowaniu przed komisją o szkody wyrządzone przy udzielaniu świadczeń związanych z profilaktyką (por. section $33.1 \mathrm{f}$ IPRCA) czy wypadki naruszenia praw pacjenta. W systemie nowozelandzkim przez treatment injury rozumie się m.in. wykonanie zabiegu bez zgody pacjenta (section 33.1 e IPRCA), nie ma przeszkód by również i w postępowaniu przed komisją naruszenie prawa pacjenta do wyrażenia zgody na wykonanie

98 M. Safjan, Prawo i medycyna. Ochrona praw jednostki a dylematy wspótczesnej medycyny, Warszawa 1998, s. 92-93.

99 Zob. szeroko powołane poglądy doktryny i orzecznictwa: M. Białkowski, Poglady doktryny prawa cywilnego i orzecznictwa na pojęcie błędu medycznego, Przegląd Prawniczy Uniwersytetu im. Adama Mickiewicza 2013, nr 2, s. 57-70. W pierwotnej wersji projektu zmian w ustawie o prawach pacjenta i Rzeczniku Praw Pacjenta ustawodawca posługiwał się zresztą pojęciem „błędu medycznego”, które w ostatecznym projekcie zostało zastąpione „zdarzeniem medycznym”.

100 M. Nesterowicz, Adekwatny związek przyczynowy jako przesłanka odpowiedzialności cywilnej w świetle orzecznictwa sadowego, w: Prawo prywatne czasu przemian. Ksiega pamiatkowa dedykowana Profesorowi Stanisławowi Soltysińskiemu, red. A. Nowicka, Warszawa 2005, s. 191. W nauce wskazuje się przy tym, że w postępowaniu przed komisją konieczne jest wykazanie istnienia adekwatnego związku przyczynowego między zdarzeniem medycznym a szkodą (zob. K. Bączyk-Rozwadowska, Odpowiedzialność cywilna..., s. 357-358; H. Frąckowiak, Postępowanie..., s. 44-45; D. Karkowska, J. Chojnacki, Postępowanie..., s. 132; Z. Cnota, G. Gura, T. Grabowski, E. Kurowska, Zasady ..., Komentarz do art. 67k, teza 5 czy M. Śliwka, Wybrane czynniki determinujące działalność wojewódzkich komisji orzekajacych o zdarzeniach medycznych, Prawo i Medycyna 2012, nr 3-4, s. 10). 
zabiegu podlegało rekompensacie (por. art. $16 \mathrm{w}$ zw. $\mathrm{z}$ art. 4 ust. 1 ustawy o prawach pacjenta i Rzeczniku Praw Pacjenta w zw. z art. 448 k.c.). Co więcej, należy postulować rozszerzenie możliwości orzekania komisji również o inne wypadki naruszenia praw pacjenta, które mogą de lega lata stanowić podstawę dochodzenia zadośćuczynienia (art. 4 ust. 3 ustawy o prawach pacjenta i Rzeczniku Praw Pacjenta).

Przechodząc do wniosków i uwag de lege ferenda w zakresie określenia kręgu podmiotów uprawnionych do dochodzenia roszczeń w postępowaniu przed wojewódzką komisją, podnieść należy, że nie budzi zastrzeżeń przyznanie uprawnienia do dochodzenia zadośćuczynienia lub odszkodowania przez pacjenta będącego osobą bezpośrednio poszkodowaną w procesie leczniczym. Istotne wątpliwości dotyczą jednak przyznania takiego uprawnienia spadkobiercom pacjenta. Sama koncepcja ochrony osób, które nie zostały bezpośrednio poszkodowane zdarzeniem medycznym, jest słuszna i zasługuje na aprobatę, jednak sposób określenia kręgu podmiotów uprawnionych poddać należy daleko idącej krytyce.

Argumentacja ustawodawcy w tym zakresie przedstawiona w uzasadnieniu projektu jest zupełnie niespójna i niejasna ${ }^{101}$, przepis art. $446 \$ 4$ K.c. nie przewiduje bowiem przyznania rekompensaty na rzecz „spadkobiercy poszkodowanego”, a już na pewno pojęcie „najbliższego członka rodziny” nie może być zrównane z pojęciem „spadkobiercy”, jak zdaje się to czynić projektodawca. Co więcej, ustawodawca nie tylko wprowadził zupełnie nową kategorię osób pośrednio poszkodowanych, ale co stanowi zupełne novum, zakreślił także ścisłe wymogi formalne, jakie muszą oni spełnić, by skutecznie złożyć wniosek o ustalenie zdarzenia medycznego (art. 67d ust. 2 pkt 3 ustawy o prawach pacjenta i Rzeczniku Praw Pacjenta). Posiadanie legitymacji czynnej ustawodawca w postępowaniu przed komisją uzależnia bowiem nie od charakteru więzi łączącej zmarłego pacjenta z osobą pośrednio poszkodowaną, a od wyczerpania formalnego kryterium bycia spadkobiercą pacjenta. Na gruncie kodeksowej regulacji przynależność do kategorii „najbliższego członka rodziny” w rozumieniu art. $446 \$ 3$ i 4 K.c. nie opiera się tylko na np. pokrewieństwie czy powinowactwie, a na rzeczywistej więzi emocjonalnej łączącej poszkodowanego ze zmarłym ${ }^{102}$. Wprowadzenie do ustawy uprawnienia spadkobierców do

101 Zob. uzasadnienia projektu ustawy o zmianie ustawy z dnia 6 listopada 2008 r. o prawach pacjenta i Rzeczniku Praw Pacjenta opublikowane na stronie internetowej Senatu RP druk nr 3488, s. 8, http:// ww2.senat.pl/k7/dok/sejm/074/3488.pdf [dostęp: 2.10.2020 r.].

102 Zob. na gruncie orzecznictwa: wyrok SN - Izba Pracy i Ubezpieczeń Społecznych z dnia 10 grudnia 1969 r., III PRN 77/69, OSNCP 1970, nr 9, poz. 160 czy wyrok SN z dnia 5 sierpnia 1970 r., II CR 313/70, OSN 1971, nr 3, poz. 56. Por. też: K. Bączyk-Rozwadowska, Roszczenia odszkodowawcze rodzin poszkodowanych pacjentów po nowelizacji kodeksu cywilnego (art. $446 \$ 4$ ), Prawo i Medycyna 2010, nr 2, s. 32-34. 
dochodzenia żądania ustalenia zdarzenia medycznego przyznaje to prawo np. osobie prawnej (art. $927 \$ 1$ K.c.) czy gminie ostatniego miejsca zamieszkania pacjenta (art. 935 zd. 1 K.c.). Konsekwencją czego może być zupełne wypaczenie kompensacyjnego charakteru świadczeń, które może uzyskać wnioskodawca w postępowaniu przed komisją.

Mając na uwadze mankamenty przyjętej regulacji, de lege ferenda postulować trzeba nowelizację przyjętego rozwiązania w celu ujednolicenia katalogu podmiotów uprawnionych do występowania w postępowaniu przed komisją oraz mających prawo do dochodzenia indemnizacji szkody w postępowaniu sądowym. Wydaje się, że najlepszym rozwiązaniem byłaby taka zmiana przepisów ustawy o prawach pacjenta i Rzeczniku Praw Pacjenta, która wprowadziłaby możliwość kompensacji szkody przed komisją przez najbliższych członków rodziny zmarłego pacjenta, jak ma to miejsce w art. $446 \$ 3$ i 4 K.c. Doprowadziłoby to - wzorem regulacji nowozelandzkiej - do oparcia uprawnienia do dochodzenia naprawienia szkody przed komisją na bliskiej więzi emocjonalnej pomiędzy zmarłym pacjentem a wnioskodawcą.

\section{Bibliografia}

Accident Compensation Corporation, Supporting Patient Safety: Treatment Injury Information, Wellington 2017.

Bagińska E., Tendencje rozwojowe odpowiedzialności deliktowej w Europie w końcu XX i poczatkach XXI wieku, w: Czyny niedozwolone w prawie polskim i prawie porównawczym, red. M. Nestorowicz, Warszawa 2012.

Bączyk K., Nowozelandzki model odpowiedzialności za szkody wyrządzone przy leczeniu, Prawo i Medycyna 2004, nr 1.

Bączyk-Rozwadowska K., Roszczenia odszkodowawcze rodzin poszkodowanych pacjentów po nowelizacji kodeksu cywilnego (art. 446\$4), Prawo i Medycyna 2010, $\mathrm{nr} 2$.

Bączyk-Rozwadowska K., Odpowiedzialność cywilna za szkody wyrządzone przy leczeniu, Torun 2013.

Białkowski M., Zmiany w Ustawie o prawach pacjenta i Rzeczniku Praw Pacjenta. Kilka uwag o mechanizmie uzyskiwania odszkodowania lub zadośćuczynienia w postępowaniu przed wojewódzkimi komisjami do spraw orzekania o zdarzeniach medycznych, Przegląd Prawniczy Uniwersytetu im. Adama Mickiewicza 2012, nr 1.

Białkowski M., Poglady doktryny prawa cywilnego i orzecznictwa na pojęcie błędu medycznego, Przegląd Prawniczy Uniwersytetu im. Adama Mickiewicza 2013, nr 2.

Biały A., Accident Compensation System - jako przykład systemu naprawienia szkody na osobie $w$ Nowej Zelandii - wybrane zagadnienia $w$ ujęciu historycznym, Studia Prawnicze KUL 2019, nr 3 (79). 
Biały A., Czyny niedozwolone w Nowej Zelandii. Accident Compensation System, Lublin 2020. Boratyńska M., Wolny wybór. Granice i gwarancje prawa pacjenta do samodecydowania, Warszawa 2012.

Boratyńska M., Konieczniak P., Prawa pacjenta, Warszawa 2001.

Brown C., Deterrence in tort and no fault: The New Zealand experience, California Law Review 1985, t. 73, nr 3 .

Cnota Z., Gura G., Grabowski T., Kurowska E., Zasady i tryb ustalania świadczeń/roszczeń (odszkodowania i zadośćuczynienia) w przypadku zdarzeń medycznych. Komentarz, 2016 [baza danych Legalis].

Cooper J., Egeberg R., Stephens S., Where is the malpractice crisis taking us?, The Western Journal of Medicine 1977, nr 127 (3).

Duffy A., The The Common-Law Response to the Accident Compensation Scheme, Victoria University of Wellington Law Review 2003, t. 34.

Dukiet-Nagórska T., O potrzebie wypracowania standardów postępowania dotyczacych niepodjęcia terapii i jej zaprzestania, Prawo i Medycyna 2008, nr 2.

Farrell A.M, Devaney S., Dar A., No-fault compensation schemes for medical injury: A review, Scottish Government Social Research 2010, http://dx.doi.org/10.2139/ssrn.2221836.

Flood C.M., New Zealand's No-Fault Accident Compensation Scheme: Paradise or Panacea?, Health Law Review 2000, t. 8, nr 3.

Frąckowiak H., Postępowanie przed Wojewódzka Komisją do spraw orzekania o zdarzeniach medycznych, Warszawa 2016.

Jończyk J., Między odpowiedzialnościa lekarza a ubezpieczeniem pacjenta, Prawo i Medycyna 1990, nr 3.

Kamiński B., Na marginesie reformy, standardów medycznych i Europejskiej Konwencji Bioetycznej - refleksje klinicysty, Prawo i Medycyna 1999, nr 3.

Karkowska D., Ustawa o prawach pacjenta i Rzeczniku Praw Pacjenta. Komentarz, Warszawa 2012.

Karkowska D., Chojnacki J., Postępowanie przed wojewódzka komisja do spraw orzekania o zdarzeniach medycznych, Warszawa 2014.

Kędziora R., Odpowiedzialność karna lekarza w związku z wykonywaniem czynności medycznych, Warszawa 2009.

Kowalewski E., Ubezpieczenia pacjentów z tytułu zdarzeń medycznych - blaski i cienie, w: Kompensacja szkód wynikłych ze zdarzeń medycznych. Problematyka cywilnoprawna i ubezpieczeniowa, red. E. Kowalewskiego, Toruń 2011.

Lean S. Mc, No Fault Compensation Review Group Report and Recommendations Volume I, Scottish Government 2011, https://www.scotland.gov.uk/Resource/0040/00401664.doc [dostęp: 5.10.2020 r.].

Marek Z., Błąd medyczny odpowiedzialność etyczno-deontologiczna i prawna lekarza, Kraków 2007.

Manning J., Treatment injury and medical misadventure, w: Medical Law in New Zealand, red. P. Skegg, R. Paterson, Wellington 2006.

Manning J., Factual causation in medical negligence, The Journal of Law Medicine 2007, nr 15 (3).

Mathieson D.L., Royal Commission of Inquiry: Compensation for Personal Injury in New Zealand, The Modern Law Review 1968, t. 31, nr 5. 
McKenzie P., The compensation scheme no one asked for: the origins of ACC in New Zealand, Victoria University of Wellington Law Review 2003, t. 34.

Nesterowicz M., Adekwatny związek przyczynowy jako przesłanka odpowiedzialności cywilnej $w$ świetle orzecznictwa sądowego, w: Prawo prywatne czasu przemian. Ksiega pamiątkowa dedykowana Profesora Stanisławowi Sołtysinskiemu, red. A. Nowicka, Warszawa 2005.

Nesterowicz M., Prawo medyczne, Toruń 2010.

Oliphant K., Accident Compensation in New Zealand, https://www.courdecassation.fr/IMG/ File/pdf_2006/05-12-2006_assurance/05-12-06_ken_oliphant-en.pdf.

Pozasądowe dochodzenie roszczeń przez pacjentów. Raport NIK, https://www.nik.gov.pl/ kontrole/P/18/057/ [dostęp: 16.11.2020 r.].

Pytlarz M., Wina anonimowa jako podstawa odpowiedzialności deliktowej za szkody wyrzadzone przy leczeniu, Prawo i Medycyna 2013, nr 1-2.

Safjan M., Prawo i medycyna. Ochrona praw jednostki a dylematy współczesnej medycyny, Warszawa 1998.

Serwach M., Ochrona ubezpieczeniowa pacjentów przed negatywnymi skutkami leczenia, Kraków 2018.

Scottish Government 2011, https://www.scotland.gov.uk/Resource/0040/00401664.doc [dostęp: $5.10 .2020 \mathrm{r}$.].

Todd S., Forty Years of Accident Compensation in New Zealand, Thomas M. Cooley Law Rewiev 2011, t. 28, nr 3.

Sośniak M., Glosa do orzeczenia Sądu Najwyższego z dnia 7 stycznia 1966, sygn. akt I CR 369/65, OSP 1966, nr 12, poz. 278.

Sośniak M., Cywilna odpowiedzialność lekarza, Warszawa 1989.

Śliwka M., Wybrane czynniki determinujace działalność wojewódzkich komisji orzekających o zdarzeniach medycznych, Prawo i Medycyna 2012, nr 3-4.

Upperton R., A truly no-fault approach to treatment injury cover in accident compensation [dysertacja], Faculty of Law Victoria University of Wellington, Wellington 2013.

Ustawa o zawodach lekarza i lekarza dentysty. Komentarz, red. E. Zielińska, Warszawa 2008. Ustawa o zawodach lekarza i lekarza dentysty. Komentarz, red. E. Zielińska, 2014 [baza danych LEX].

Wierczyński G., Komentarz do rozporzadzenia w sprawie „Zasad techniki prawodawczej”, w: Redagowanie i ogłaszanie aktów normatywnych. Komentarz, 2009 [baza danych LEX].

Zieliński M., Wykładania prawa. Zasady, reguły, wskazówki, Warszawa 2008. 